\title{
Reptiles of Ngulu Atoll, Yap State, Federated States of Micronesia ${ }^{1}$
}

\author{
Donald W. Buden ${ }^{2}$
}

\begin{abstract}
Fourteen species of reptiles (two sea turtles, six geckos, six skinks) are recorded from Ngulu Atoll, Yap, Micronesia, all but the turtles for the first time. None is endemic and most occur widely in Oceania; the phylogenetic status of an undescribed species of Lepidodactylus is undetermined, and a phenotypically male Nactus cf. pelagicus is recorded from Micronesia for the first time. Lepidodactylus moestus is the most common gecko on Ngulu Island, and Emoia caeruleocauda, E. impar, and E. jakati are the most abundant skinks. The islands are an important nesting site for green turtles, Chelonia mydas. Isolation, a small resident human population, and traditional conservation practices contribute to sustaining turtle populations, although occasional poaching by outside visitors persists. The report of a small snake on Ylangchel Island, possibly a species of Ramphotyphlops, requires confirmation.
\end{abstract}

Many of THE west-central Pacific islands composing Micronesia are poorly known biologically, especially the numerous, small, lowlying, and faunistically impoverished coralline atolls. These islands are difficult to reach. Those that have been studied appear to be inhabited largely by widespread, weedy species that are common also on the high, volcanic islands, which offer contemporary visiting biologists both easier access and a richer biota to investigate. Much of the albeit scanty information on the more remote islands stems from the nineteenth- and early twentiethcentury European voyages of exploration that involved many months at sea. But an understanding of the biogeography of Oceania remains incomplete without a more thorough assessment of the distribution and abundance of plants and animals on these minuscule parcels of land. The terrestrial biota of Ngulu Atoll, Yap, for example, has never been surveyed. This study is the first report on the

\footnotetext{
${ }^{1}$ Manuscript accepted 19 June 2009.

2 Division of Natural Sciences and Mathematics, College of Micronesia-FSM, P.O. Box 159, Kolonia, Pohnpei, Federated States of Micronesia 96941 (e-mail: don_buden@comfsm.fm).
}

Pacific Science (2010), vol. 64, no. 3:473-480 doi: $10.2984 / 64.3 .473$

(C) 2010 by University of Hawai'i Press

All rights reserved distribution and relative abundance of the reptiles of Ngulu, and it is based largely on my personal observations and specimens that I collected during approximately a monthlong field study, mainly on Ngulu Island, and with brief visits to adjacent Ylangchel and Wachlug islands. Results of concomitant surveys of birds, butterflies, and dragonflies will be published elsewhere.

\section{Study Area}

Ngulu Atoll $\left(8^{\circ} 17^{\prime}\right.$ to $8^{\circ} 34^{\prime} \mathrm{N}$ and $137^{\circ} 25^{\prime}$ to $137^{\circ} 35^{\prime} \mathrm{E}$ ) is located in the western Caroline Islands, in Yap State, Federated States of Micronesia (FSM), approximately $100 \mathrm{~km}$ southwest of Yap proper and $300 \mathrm{~km}$ eastnortheast of the Republic of Belau (Palau). The atoll is approximately $40.0 \mathrm{~km}$ long (north to south) but has a total land area of approximately only $0.3 \mathrm{~km}^{2}$ distributed among two northern and three southern islands (Figure 1); Ngulu Island $\left(0.1 \mathrm{~km}^{2}\right)$ is the largest and southernmost. Bryan (1971) mentioned other islets on the atoll, but all those I saw were tiny sand cays or gravel bars devoid of vegetation and likely awash during high tides and storms, and they are not recognized as distinct islands by Ngulu residents.

Coconut (Cocos nucifera) forest is the main vegetation type, at least on the three southern islands. Scaevola (S. taccada) thickets occur in 


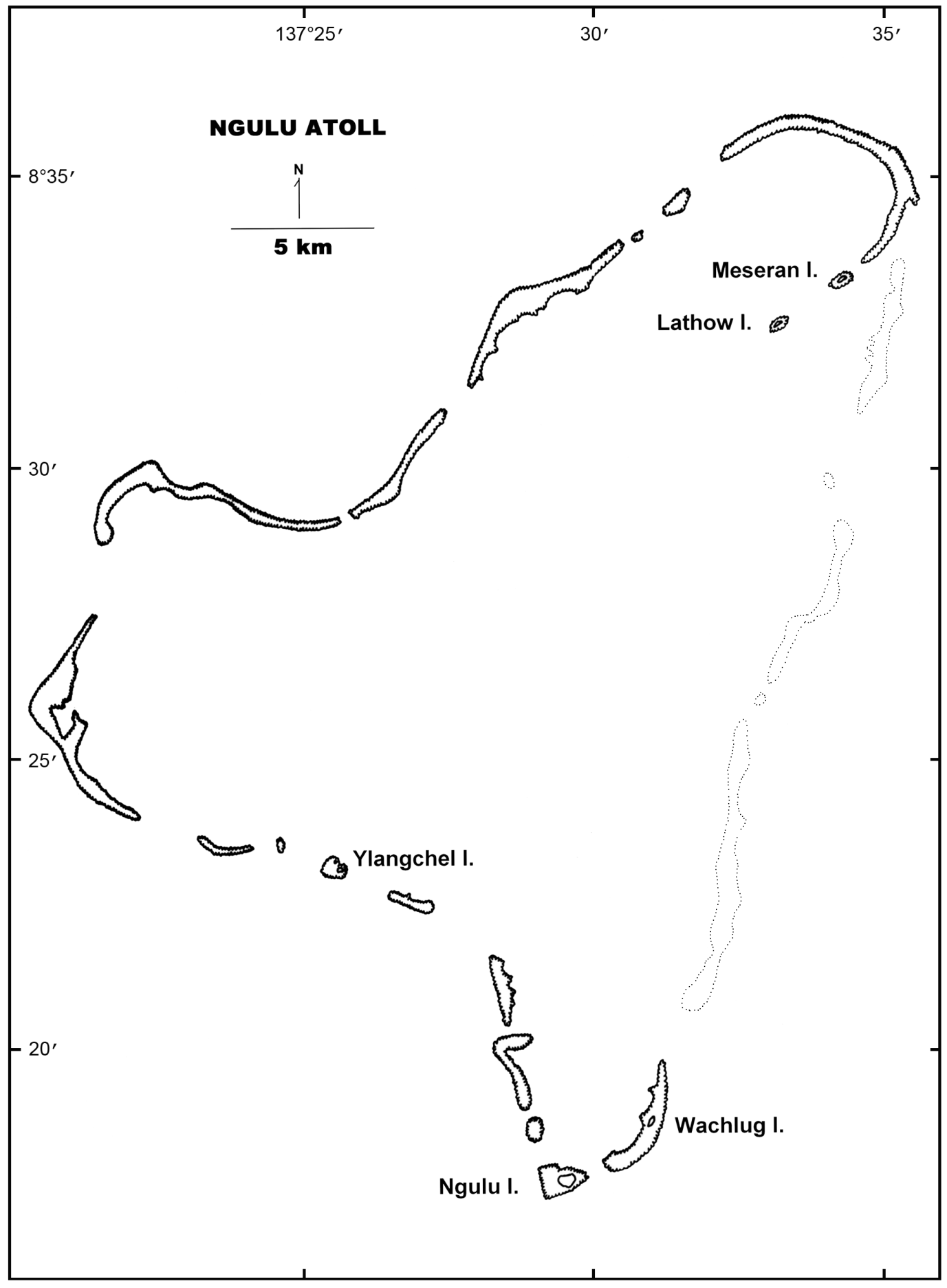

FIgURE 1. Location map for islands of Ngulu Atoll. 
patches along the upper beach on Ngulu and Wachlug islands but apparently are absent from Ylangchel, which is higher than the other islands (ca. $4-5 \mathrm{~m}$ in elevation), has a rocky shoreline devoid of any sandy beaches, and has a grove of tree heliotrope (Tournefortia argentea) on the lagoon side that hosts numerous breeding seabirds of several species. Eight people were living on Ngulu Island at the time of this study, but more than 100 resided at times during the late 1900s (M. Ragmau, pers. comm.); the four other islands are uninhabited. The two northern islands were not visited during this survey, but Kolinski $(1993 a, b)$ described them as having beaches mainly of sand (Meseran Island) or coral rock and sand (Lathow Island [= North Island]) and being moderately vegetated with shrubs, trees (e.g., coconut; breadfruit, Artocarpus spp.; and papaya, Carica papaya), and patches of grass.

\section{MATERIALS AND METHODS}

Fieldwork was conducted on Ngulu Island during 13 July-10 August 2008, with brief visits to nearby Wachlug (= Uatschaluk) Island on 18 and 19 July, and Yalangchel (= Jalangaschel) Island on 27 July and 9-10 August 2008. Two hundred and twenty three specimens of 12 species of lizards were collected by hand, fixed in $10 \%$ formalin, and transferred to $35 \%$ isopropanol (Table 1); tissue samples from several Lepidodactylus spp. were preserved in ethanol for later study. Specimens were deposited in the Bishop Museum (врвм); California Academy of Sciences (cas); Museum of Comparative Zoology, Harvard University (MCZ); U.S. Geological Survey San Diego Field Station; and the National Museum of Natural History, Smithsonian Institution (USNM). Measurements of turtles were recorded in inches using a metal tape measure and later converted to centimeters. Carapace length was measured as the straight-line distance from the middle of the nuchal notch to the posteriormost edge of the shell, and carapace width as the straightline distance across the widest part of the shell. Herpetological data for the two northern islands are limited to turtles and are based largely on the work of Kolinski (1993a,b, 1994, 1995).

\section{RESULTS}

\section{Turtles}

Chelonia mydas (Linnaeus). Pritchard (1977) reported that green turtles nest on the two northern islands of Ngulu Atoll but gave no indication as to numbers. Kolinski (1994) briefly mentioned a turtle tagging and monitoring program conducted on Lathow $(=$ Losau $=$ North $)$ Island and on Meseran Island in 1992 and 1993. During the 1992 survey (3 May-22 July), 54 (78\%) of the 69 females found on land were encountered during the month of May, 73 adult C. mydas were tagged, 225 nests were recorded (187 on Meseran, 38 on Lathow), and a total of five mating couples was observed, the last being in early July (Kolinski 1993a). During the 1993 survey (10 days on Lathow and 57 on Meseran, between 22 April and 15 July), 78 adult females were tagged (63 on Meseran [plus 2 in nearby shallows], and 13 on Lathow), a minimum of 107 nests were laid (on Meseran), and five mating couples were observed, the last being in early May (Kolinski 1993b).

I observed green turtles nesting on Ngulu Island regularly during the last 2 weeks of July and first week of August 2008, and a visitor from Yap told me of seeing at least two mating pairs at Ngulu Island on several different occasions during 6-9 August. I recorded a maximum of five turtles that came ashore during the night of 18/19 July, and George Mangthaw, the resident caretaker for the island, remarked (pers. comm.) that 10 nested in one night earlier in July, just before my arrival, and he recalled a maximum of 15 nesting in one night during the 2004 season. Children from the village found four hatchlings on the beach at one site and another at a different site during the afternoon of 6 August 2008, and 115 eggs were removed from a nest on the same day. Eggs also were collected from several nests by visitors to Wachlug Island during 9/10 August. I saw numerous old tracks on Wachlug during my 
visit on 18 and 19 July but saw no turtles nesting. Turtles do not nest on Ylangchel Island, which is completely surrounded by rocky and, for the most part, steep-sided beaches.

I measured nine females that were captured on shore on Ngulu Island during midJuly to early August: carapace length 89.5$100.3 \mathrm{~cm}$ (avg. $96.0 \mathrm{~cm}$ ), carapace width 69.2-79.4 cm (avg. $74.1 \mathrm{~cm}$ ). The turtles were intended for consumption by the island residents and the chief's family and guests of honor who were expected to arrive from Yap proper on the next ship. Ngulu tradition allows for the killing of turtles for food only when the chief is present on the island, although eggs may be harvested at other times. However, M. Ragmau and G. Mangthaw (pers. comm.) both indicate that poaching by visitors from Yap proper and elsewhere occurs, and, because of the relative inaccessibility of these islands, turtle populations cannot be monitored regularly.

Pritchard (1977) remarked that the population of green turtles on Ngulu Atoll is unusual in having an early nesting season, with turtles being well into nesting activity in February. However, Mike Ragmau (pers. comm.) recognizes two separate nesting seasons: May-August, when most of the turtles nest, and December-March, when only a few nest.

Eretmochelys imbricata (Linnaeus). Two adult hawksbills were encountered in the northern islands during the 1992 tagging/ monitoring program, one on Lathow (not nesting), and the other on Meseran, where it had nested (Kolinski 1993a). The tracks of two hawksbills were observed the following year, one each on Lathow and Meseran, but the turtles were not observed (Kolinski 1993b). At the time of the 1992/1993 surveys, Ngulu islanders indicated that two to three hawksbills would be expected to nest in the northern islands each season (J. Gap in Kolinski [1993b]). None was observed during the study reported here. Chief Mike Ragmau (pers. comm.) stated that hawksbills used to nest on Ngulu Atoll in small numbers (no more than an estimated four or five per season). He indicated that they may still breed on the seldom-visited northern islands, but that he had not seen any on the atoll since about the year 2000 .

\section{Lizards}

Geckos:

Gebyra mutilata (Wiegmann). The stumptoed or mutilating gecko is relatively uncommon on Ngulu Island. Only seven specimens were recorded during the approximately month-long study (Table 1): four in edificarian habitats (buildings, walls, and other examples of human construction), three on tree trunks, and one on the ground under a decomposing palm-frond basket. None was encountered on Wachlug and Ylangchel islands.

Gebyra oceanica (Lesson). The oceanic gecko was common at night on the walls of buildings and scaevola shrubs along the beach, and less frequently encountered on tree trunks (Table 2). During the day, it was occasionally encountered in the leaf axils of coconut trees.

Lepidodactylus lugubris (Dumeril \& Bibron). The mourning gecko is a unisexual, parthenogenetic species widely distributed in the Pacific. It is often found in close association with humans, and its widespread distribution

\section{TABLE 1}

Distribution of Lizards Collected on Three Different Islands on Ngulu Atoll during 13 July-10 August 2008

\begin{tabular}{lrcc}
\hline \hline Lizards & Ngulu & Ylangchel & Wachlug \\
\hline Geckos & & & \\
$\quad$ Gehyra mutilata & 7 & & \\
$\quad$ Gehyra oceanica & 8 & 3 & 1 \\
$\quad$ Lepidodactylus lugubris & 98 & 10 & 4 \\
$\quad$ complex ${ }^{a}$ & & & \\
$\quad$ Nactus cf. pelagicus & 6 & 3 & \\
Skinks & & & \\
$\quad$ Emoia atrocostata & 16 & 2 & $\mathrm{SR}^{b}$ \\
$\quad$ Emoia caeruleocauda & 15 & & \\
$\quad$ Emoia impar & 22 & 1 & 1 \\
$\quad$ Emoia jakati & 20 & & 1 \\
Eugongylus albofasciolatus & 1 & & \\
Lamprolepis smaragdina & 2 & 1 & 1 \\
\end{tabular}

Note: Numbers do not necessarily indicate relative abundance.

${ }^{a}$ Includes L. lugubris, L. moestus, and L. sp. undescribed.

${ }^{b}$ Sight records only. 
TABLE 2

Observation Rate (Animals per Hour) and Percentage Frequency of Encounters of Geckos in Four Habitats on Ngulu Island

\begin{tabular}{|c|c|c|c|c|}
\hline \multirow[b]{2}{*}{ Species } & \multirow{2}{*}{$\begin{array}{c}\text { Day } \\
\begin{array}{c}\text { Coconut Leaf Axils } \\
1.7 / 21 \%\end{array}\end{array}$} & \multicolumn{3}{|c|}{ Night } \\
\hline & & $\begin{array}{c}\text { Tree Trunks } \\
2.3 / 29 \%\end{array}$ & $\begin{array}{c}\text { Scaevola Shrubs } \\
2.5 / 32 \%\end{array}$ & $\begin{array}{c}\text { Edificarian } \\
1.4 / 18 \%\end{array}$ \\
\hline Gebyra mutilata & & $0.9 / 67 \%$ & & $0.7 / 33 \%$ \\
\hline Gebyra oceanica & $3.6 / 12 \%$ & $2.2 / 10 \%$ & $9.9 / 49 \%$ & $10.6 / 29 \%$ \\
\hline Lepidodactylus lugubris complex ${ }^{a}$ & $2.4 / 4 \%$ & $4.9 / 16 \%$ & $20.5 / 73 \%$ & $3.5 / 7 \%$ \\
\hline Nactus cf. pelagicus & & $0.4 / 11 \%$ & & $5.7 / 89 \% b$ \\
\hline
\end{tabular}

probably in large measure is human assisted (Zug 1991, Moritz et al. 1993, Bauer and Henle 1994). It appears to be relatively uncommon on Ngulu Atoll because only 6 of the 112 Lepidodactylus collected during this study are provisionally identified as this species based on their coloration and pattern. Three were collected in scaevola shrubs, another on a cement wall, another on driftwood on a coral-rubble beach, and one on a tree trunk, all on Ngulu Island.

Lepidodactylus moestus (Peters). The Micronesian scaly-toed gecko is the most common species of gecko, and one of the most common lizards, on Ngulu Atoll; it was especially abundant on scaevola shrubs along the beach, at night (Table 2). Of the 98 examples of this genus collected on Ngulu Island, 70 (71\%) have been provisionally identified as this species. Fifty-six were collected on scaevola shrubs, and the remainder on tree trunks (4), in palm leaf axils (2), in edificarian habitats (7), and as prey taken from a chicken in the settlement (1). Three others from Wachlug Island were collected on scaevola shrubs.

Lepidodactylus species. Among the 112 specimens of Lepidodactylus collected on Ngulu Atoll, 33 appear to be examples of one or more bisexual species other than $L$. moestus but different from the one that has been recorded in Polynesia and the Marshall Islands (R. Fisher, pers. comm.; see also Ineich and Ota [1992] and Radtkey et al. [1995]). The Ngulu material may include ex- amples of a species that Crombie and Pregill (1999) recorded in Palau and that they considered also different from the Polynesia/ Marshall Islands populations.

Nactus cf. N. pelagicus (Girard). The Nactus pelagicus complex comprises several morphologically very similar bisexual and unisexual species found in northern Australia and the islands of southwestern Oceania ( $\mathrm{Zug}$ and Moon 1995, Zug 1998). With the exception of an as yet undescribed bisexual species from Palau (see Crombie and Pregill 1999), only the unisexual $N$. pelagicus has been recorded in Micronesia (Zug and Moon 1995). But among the nine specimens from Ngulu Atoll is a male (preserved with hemipenes everted) taken on a tree trunk on Ylangchel Island on 10 August: the first example of a male of the genus Nactus recorded in the FSM. The specimen is provisionally treated as $N$. pelagicus based on an initial examination of its external morphology and pending more detailed comparisons, including assessment of gonad histology (G. Zug, pers. comm.). Its male phenotype possibly is the result of a meiotic and developmental anomaly similar to that which Röll and von Düring (2008) described for rarely occurring and presumably sterile males of Lepidodactylus lugubris. One female $N$. cf. pelagicus was collected on a tree trunk, also on Ylangchel, and at approximately the same time as the male. The seven others were collected on Ngulu Island, one on a tree trunk, one on rocky ground in for- 
est, and the remainder in edificarian habitats, including cement and wood buildings and on or immediately adjacent to stone walls.

\section{Skinks:}

Emoia atrocostata (Lesson). The littoral skink is locally common along rocky beaches on all three southern islands, and with up to five or six being encountered along sections of shoreline approximately 20 to $30 \mathrm{~m}$ long on parts of Ngulu and Ylangchel islands. Some were observed foraging on rocky reef flats during low tide and at least $10-15 \mathrm{~m}$ from the shoreline. Those on Ylangchel were darker dorsally than those on Wachlug and Ngulu islands, being dark gray (some nearly black) as opposed to silvery gray.

Emoia jakati (Kopstein). The Jakati skink is very common on Ngulu Island, being most numerous in the settlement and in the adjacent coconut forest, especially in sparse grasses and leaf litter, often on nearly bare ground. It was especially common under breadfruit trees at the edge of the settlement (195/hr during a 48 min search effort) but much less numerous in more densely vegetated Cocos forest (12/hr; $25 \mathrm{~min})$. It often attempted to avoid capture by running around the base of a tree and entering available holes and fissures, but it never ascended the trunk more than a few centimeters. I saw it regularly also in the more open, grassy, weedy patches on Wachlug Island but did not encounter it on Ylangchel Island.

Emoia caeruleocauda (De Vis). The Pacific blue-tailed skink is common on Ngulu Island, being most numerous in forest, mainly on the forest floor and low on tree trunks and in the understory. The maximum encounter rate was $19.2 / \mathrm{hr}$ on the forest floor during a 25 min search in Cocos forest. It was unrecorded on Ylangchel and Wachlug islands.

Emoia impar (Werner). The blue-tailed copper-striped skink is common throughout the three southern islands and probably the most abundant skink on the atoll. It was most numerous in forest habitats but regularly observed also in the settlement and occasionally inside buildings. The maximum encounter rate was $43.2 / \mathrm{hr}$ on the forest floor during a 25-min search in Cocos forest on Ngulu Island.

Eugongylus albofasciolatus (Günther). Only two reclusive litter skinks were observed during approximately 1 month on the atoll, both of them in the settlement: one at the edge of the coconut forest in palm litter and the other at the base of a stone wall. This species is probably more common than the records indicate, but its secretive habits and tendency to quickly seek shelter when disturbed make assessment difficult.

Lamprolepis smaragdina (Lesson). The green tree skink was fairly common on tree trunks and only occasionally seen on the ground. Of the 28 for which I noted dorsal coloration, one of the eight from Ngulu Island was recorded as greenish brown and all the others (including 20 on Wachlug Island) were green.

\section{DISCUSSION}

At least 14 species of reptiles are known from Ngulu Atoll: two sea turtles, six geckos (including an as yet undescribed species of Lepidodactylus [R. Fisher, pers. comm.]), and six skinks. In addition, the chief of Ngulu (pers. comm.) remarked on seeing a small snake in a palm leaf axil on Ylangchel Island that generally fits the description of a species of Ramphotyphlops, possibly $R$. braminus, which has been introduced widely in tropical and subtropical areas world-wide, or, alternatively, an example of an as yet undescribed species, possibly one currently under study and thus far known only from Ulithi Atoll, Yap (Wynn et al. in prep). But the record of a snake on Ngulu Atoll remains hypothetical in the absence of more conclusive supporting evidence. None was encountered on Ylangchel during my 2- to 3-hr daytime search on 27 July nor during a search of several hours the night of 9/10 August with M. Falanruw and several of her associates, who had arrived via the government field trip ship.

Geckos and skinks compose the largest component of the herpetofauna on Ngulu Atoll (at least 85\%), as they do on other islands throughout the FSM (e.g., Buden 
[2000] and pers. obs.). No quantitative studies were done to assess how 12 species of lizards partition resources on Ngulu Island, a land area of only approximately 10 ha, but incidental observations indicate that they are separated by different combinations of body size (and presumably prey size), preferred perching sites, and activity periods. The 12 species are divided equally between nocturnal geckos (6) and diurnal skinks (6). Three of the skinks are relatively large and roughly similar in body size, with adults often exceeding $75 \mathrm{~mm}$ in snout-vent length (SVL). Among these, Lamprolepis smaragdina is almost entirely arboreal, Eugongylus albofasciolatus is terrestrial in forest and disturbed areas, often in or near dense cover, and Emoia atrocostata occurs mainly along the shoreline on exposed rocky beaches. The three smaller species (SVL ca. 40-60 mm), all members of the genus Emoia, occur islandwide: Emoia jakati occurs mainly in open, sparsely vegetated areas and is strictly terrestrial, whereas E. caeruleocauda and $E$. impar are broadly syntopic in forest and disturbed areas, at least on Ngulu Island, on the ground and on tree trunks and understory vegetation. However, Emoia impar is relatively more numerous in more open sunexposed areas, and E. caeruleocauda is more frequently encountered in shaded forest.

Among the geckos, Gebyra oceanica is considerably larger than the others and doubtless feeds on much larger prey; Nactus cf. pelagicus has a predilection for rocky areas and is usually seen on the ground and low on large tree trunks and on stone and cement walls. The remaining species occur in a variety of habitats, including relatively undisturbed forest and coastal scrub as well as edificarian and ruderal habitats. Members of the Lepidodactylus lugubris complex are especially numerous in scaevola shrubs.

With the exception of Emoia atrocostata, whose range in the Caroline Islands does not extend east of Yap proper and Ulithi Atoll, the species of reptiles found on Ngulu occur widely on atolls and high islands throughout the FSM. On the other hand, several common and widespread Micronesian species are unrecorded on Ngulu. They are Perochirus ateles, Emoia cyanura, E. boettgeri, and Lipinia noctua. Of these, L. noctua is the most cryptic and one of the least frequently encountered lizards on islands elsewhere in the FSM. It may have been present but overlooked on Ngulu. The three other species are usually common and conspicuous where they occur elsewhere in the FSM, and their absence on Ngulu, at least on the three southern islands, is likely real. Overall, the herpetofauna of Ngulu is typical of that found on small coralline islands elsewhere in the FSM.

\section{ACKNOWLEDGMENTS}

I am grateful to Steve Goodall for transport to Ngulu Atoll aboard the yacht Manta and to Chief Mike Ragmau and George Mangthaw for their assistance during my stay. I also thank George Balazs and Steven Kolinski for providing information on nesting turtles, and Robert Fisher and George Zug for assistance with identification of lizards in the genera Lepidodactylus and Nactus, respectively.

\section{Literature Cited}

Bauer, A. M., and K. Henle. 1994. Family Gekkonidae (Reptilia, Sauria), I. Australia and Oceania. Das Tierreich, Teilband 109. Walter de Gruyter, Berlin.

Bryan, E. H., Jr. 1971. Guide to place names in the Trust Territory of the Pacific Islands. Pacific Science Information Center, Bishop Museum, Honolulu.

Buden, D. W. 2000. The reptiles of Pohnpei, Federated States of Micronesia. Micronesica 32:155-180.

Crombie, R. I., and G. K. Pregill. 1999. A checklist of the herpetofauna of the Palau Islands (Republic of Belau), Oceania. Herpetol. Monogr. 13:20-80.

Ineich, I., and H. Ota. 1992. Additional remarks on the unisexual-bisexual complex of the gecko Lepidodactylus lugubris, in Takapoto Atoll, French Polynesia. Bull. Coll. Sci. Univ. Ryukyus 53:31-39.

Kolinski, S. P. 1993a. Outer island turtle project: Stage III report on Ngulu Atoll fieldwork. Marine Resources Management 
Division, Yap, Federated States of Micronesia.

1993b. Outer island turtle project:

Stage IV report on Ngulu Atoll fieldwork.

Marine Resources Management Division, Yap, Federated States of Micronesia.

. 1994. Carapace lesions of Chelonia mydas breeding in Yap State are diagnosed to be fibropapilloma. Mar. Turtle Newsl. 67:26-31.

. 1995. Migrations of the green turtle, Chelonia mydas, breeding in Yap State, Federated States of Micronesia. Micronesica 28:1-8.

Moritz, C., T. J. Case, D. T. Bolger, and S. Donellan. 1993. Genetic diversity and the history of the Pacific island house geckos (Hemidactylus and Lepidodactylus). Biol. J. Linn. Soc. 48:113-133.

Ota, H., R. N. Fisher, I. Ineich, and T. J. Case. 1995. Geckos of the genus Lepidodactylus (Squamata: Reptilia) in Micronesia: Description of a new species and reevaluation of the status of Gecko moestus Peters, 1867. Copeia 1995:183-195.
Pritchard, P. C. H. 1977. Marine turtles of Micronesia. Chelonia Press, San Francisco.

Radtkey, R. R., S. C. Donnellan, R. N. Fisher, C. Moritz, K. A. Hanley, and T. J. Case. 1995. When species collide: The origin and spread of an asexual species of gecko. Proc. R. Soc. Lond. B Biol. Sci. 259:145-152.

Röll, B., and M. U. von Düring. 2008. Sexual characteristics and spermatogenesis in males of the parthenogenetic gecko Lepidodactylus lugubris (Reptilia, Gekkonidae). Zoology (Jena) 111:385-400.

Zug, G. R. 1991. The lizards of Fiji: Natural history and systematics. Bishop Mus. Bull. Zool. 2:1-136.

1998. Australian populations of the Nactus pelagicus complex (Reptilia: Gekkonidae). Mem. Queensl. Mus. 42:613-626.

Zug, G. R., and B. R. Moon. 1995. Systematics of the Pacific slender-toed geckos, Nactus pelagicus complex: Oceania, Vanuatu, and Solomon Islands populations. Herpetologica 51:77-90. 